\title{
Visceral Leishmaniasis in the Metropolitan Region of Belo Horizonte, State of Minas Gerais, Brazil
}

\section{Eduardo S Silva/ ${ }^{+}$, Célia MF Gontijo, Raquel S Pacheco*, Vanessa OP Fiuza**, Reginaldo P Brazil}

\author{
Laboratório de Leishmanioses, Centro de Pesquisas René Rachou-Fiocruz, Av. Augusto de Lima 1715, 30190- \\ 002 Belo Horizonte, MG, Brasil *Laboratório de Sistemática Molecular, Departamento de Bioquímica e Biologia \\ Molecular, Instituto Oswaldo Cruz-Fiocruz, Rio de Janeiro, RJ, Brasil **Serviço de Controle de Doenças \\ Transmissíveis, Secretaria Estadual de Saúde, Belo Horizonte, MG, Brasil
}

In the last few years the number of human cases of American visceral leishmaniasis in the Metropolitan Region of Belo Horizonte (MRBH), Minas Gerais, Brazil has increased, indicating an elevation in the transmission rate of the disease. The total number of notified human cases in the MRBH since 1994, when the first case was identified, up to 1999 was 345 of which 223 (65\%) were from the city itself, indicating an urbanization of the disease in this region of Minas Gerais. The age distribution of visceral leishmaniasis cases in the MRBH shows a higher prevalence in children from 0-4 years old, responsible for $28.9 \%$ of the notifications. Clinical and immunological findings from dogs infected with Leishmania chagasi are described. The majority of these animals showed no sign of the disease. Sera from all infected dogs showed detectable Leishmania-induced high titles of antibodies based on the results of an indirect fluorescent antibody test. Samples of isolated Leishmania from human and dogs were characterized as L. (L.) chagasi by biochemical and molecular techniques.

Key words: visceral leishmaniasis - epidemiology - human - dogs - Leishmania chagasi - Minas Gerais - Brazil

American visceral leishmaniasis (AVL) in Brazil is considered to be a zooanthroponosis formerly restricted to rural and peri-urban areas. With the emergence of foci of the disease in urban areas, visceral leishmaniasis (VL) has assumed an important role in public health (Marzochi et al. 1994).

Leishmania (Leishmania) chagasi is the etiological agent responsible for the disease in several endemic areas of VL in Latin America (Lainson \& Shaw 1987, Grimaldi \& Tesh 1993).

AVL manifestations in humans differ little from the clinical/epidemiological forms existing on other continents. Symptoms include fever, anemia, hepatosplenomegaly and progressive weight loss, although the disease is quite sensitive to treatment with antimonial drugs (Marzochi et al. 1994). The mortality rate for untreated cases varies from 75$95 \%$, although the existence of an asymptotic and subclinical form has been acknowledged (Marzochi et al. 1985, Badaró et al. 1986). According to the Ministry of Health, more than 1,000 human cases occur annually in Brazil.

\footnotetext{
Supported by CNPq, Papes II/Fiocruz.

${ }^{+}$Corresponding author. Fax: +55-31-3295.3115. E-mail: pheolei@hotmail.com; silvarii@cpqrr.fiocruz.br Received 7 June 2000

Accepted 29 November 2000
}

The domestic dog is an important reservoir and is responsible for the endemic/epidemic nature of the disease. Foxes belonging to the species Lycalopex vetulus in the northeast (Deane \& Deane 1954) [Now it may be referred as Cerdocyon thous (Courtenay et al. 1996)] and C. thous in the Amazon (Lainson et al. 1969, 1987, Silveira et al. 1982) southeast region (Silva et al. 2000), and Central Brazil (Mello et al. 1988) act as natural hosts and are responsible for the disease in sylvatic environments. Human beings are a weak source of $L$. $(L$.) chagasi infection for phlebotomine sand flies and transmission largely depends on the presence of infected dogs (Lainson \& Shaw 1987). Domestic dogs and foxes may present an intense cutaneous parasitism that allows sand flies to become infected easily (Deane \& Deane 1954). However, there are probably other sources of infection and it is possible that man is involved in the transmission cycle (Badaró et al. 1994, Nascimento et al. 1996).

The pattern of clinical signs of the disease in dogs may vary considerably as animals which are apparently healthy, or with inapparent infections, can present signs at several stages of the disease. An important characteristic of leishmaniasis in dogs is the presence of clinically inapparent disease for long periods. The constant presence of infected dogs also contributes to spread the disease during migrations of human beings from endemic to nonendemic areas (Arias et al. 1996). 
In the last few years, the number of human and canine cases of AVL in the Metropolitan Region of Belo Horizonte (MRBH) in the State of Minas Gerais (MG), Brazil, has increased, suggesting an increase in the rate of transmission of the disease.

The general objective of this study was to determine the distribution, prevalence, incidence and symptomatology of AVL in humans and dogs in endemic area of MRBH. In addition, we used different molecular techniques for the characterization of parasite isolates from these hosts.

\section{MATERIALS AND METHODS}

Study area - MRBH is located in the area of MG known as the "Zona Metalúrgica" and occupies an area of $6,000 \mathrm{~km}^{2}$ composed of 24 counties. Belo Horizonte $(\mathrm{BH})$ is the state capital and has an estimated population of 3,753,092 inhabitants. The economy of the region is based on industries, agriculture, trade and mineral extraction and $30 \%$ of the population of MG live in this area.

Mountains surround the county and being located between latitudes $18-20^{\circ} \mathrm{S}$ and longitudes $43-45^{\circ} \mathrm{W}$ presents a tropical climate, with a rainy summer and dry winter.

Canine survey - One hundred and sixty-four domestic dogs, consisting of 83 males $(50.6 \%)$ and 81 females (49.4\%) from several districts of $\mathrm{BH}$ and nearby municipalities within the MRBH were studied from 1998 to 1999.

Animals were examined for the presence, number and localization of ulcers on their bodies. Peripheral blood samples were collected for serological diagnosis of the animals. IFAT was used to detect antibodies in sera of all studied dogs using a kit for canine leishmaniasis (Fiocruz/BioManguinhos). Serum dilutions from 1:40-1:640 were used.

For parasitological diagnosis, dogs were sedated with $10 \mathrm{mg} / \mathrm{kg}$ of Ketamine and $1 \mathrm{mg} / \mathrm{kg}$ of Xylazine $\left(\right.$ Ketalar ${ }^{\circledR}+$ Rompum $\left.{ }^{\circledR}\right)$ by intramuscular injection. Aspiration of bone marrow from the tibia was performed using a $20 \mathrm{ml}$ syringe with 18 gauge needle. In dogs showing any type of lesion, a small fragment of the ulcer was taken for microscopic preparation and culture in NNN medium. In the case of ulcerated lesions, part of the material was inoculated in hamsters (Mesocricetus auratus) and eventually seeded in NNN/LIT.

Human survey - A retrospective study of incidence data for human VL in MRBH between 1994 and 1999 was carried out. The data were obtained from the Secretaria Estadual de Saúde. To establish the annual incidence for the period, we considered the information relative to age, sex, symptomatology, clinical, parasitological or immunological diagnosis, and the confirmed address of all patients.
Isolation and characterization of parasites Fourteen isolates were analyzed: 10 from dogs $(9$ from bone marrow, 1 from skin lesion), and 4 from the bone marrow of AVL patients. Leishmania parasites obtained from dogs and humans were cultured in NNN/LIT supplemented with $10 \%$ of foetal bovine serum at $26^{\circ} \mathrm{C}$. Parasites in the stationary phase were harvested by centrifugation at $3,000 \mathrm{rpm}$ for $10 \mathrm{~min}$ at $4^{\circ} \mathrm{C}$ and washed several times with sterile phosphate buffered saline $(\mathrm{pH}$ 7.2).

Multi-locus enzyme electrophoresis - Isoenzyme electrophoresis was performed using a system of 11 enzymatic loci (6PGDH, E.C.1.1.1.43; GPI, E.C.5.3.1.9; IDH, E.C.1.1.1.42; G6PDH, E.C.1.1.1.1.49; $\mathrm{MDH}$, E.C.1.1.1.37; NH, E.C.3.2.2.1; PGM, E.C.1.4.1.9; PEP-D, E.C.3.4.13.9; ME, E.C.1.1.1.40; IDH, E.C.1.1.1.42; ACON, E.C.4.2.1.3) using 1\% agarose gel electrophoresis as described by Momem and Salles (1985), and Pacheco et al. (1994).

kDNA analysis and Southern blot hybridization - Extraction and analysis of kDNA restriction profiles was carried out according to Pacheco et al. (1986). Purified kDNA preparations $(1 \mu \mathrm{g})$ were digested with the restriction enzymes Msp I and Mbo I in the appropriate buffers according to the manufacturer's instructions. After electrophoresis, fragments were transferred to nylon membranes using the method of Southern (1975). Probes composed of cloned minicircles from $L$. (L) chagasi were radiolabeled with $\propto{ }^{32} \mathrm{P}$ dATP using the random primer method (Kit Fiocruz, Brazil) to an specific activity of about $10^{9} \mathrm{dpm} / \mu \mathrm{g}$ according to a modified protocol (Pacheco et al. 1994). Hybridizations were carried out at $65^{\circ} \mathrm{C}$ overnight, membranes were washed in $0.1 \times \mathrm{XSC} / 0.5 \% \mathrm{SDS}$ at $65^{\circ} \mathrm{C}$ three times, $30 \mathrm{~min}$ each and exposed to $\mathrm{X}$-ray films overnight with an intensifying screen at $-70^{\circ} \mathrm{C}$.

\section{RESULTS}

Characterization of human disease - By 1999 , 345 autochthonous cases had been diagnosed in $\mathrm{MRBH}$, being $223(65 \%)$ in the county of $\mathrm{BH}$ alone. The distribution and incidence rate of the disease is shown in Table I.

Seventy six percent of registered cases in $\mathrm{BH}$ in 1994 occurred in people under 14 years old. However the age distribution of the 345 notified cases of AVL in MRBH from 1994-1999 shows the highest prevalence among children from 0-4 years old with nearly $28.9 \%$ of the notifications. The second highest prevalence was observed in the economically productive 15-29 age group, mostly among males (Table II). The VL lethality rate in MRBH between 1994-1999 was 11.5\% (Table III). 
The Figure shows the distribution of AVL cases according to evolution, cure, death and relapse. Past or present fever, generally the commonest human visceral leishmaniasis symptom, was reported by all patients. Hepatomegaly and splenomegaly were the most frequent manifestations of the disease and hemorrhage the least common (Table IV).

\section{Canine survey}

Serological test - The indirect immunofluorescence test was positive in 106 (64.6\%) out of 164 dogs examined from areas where AVL was the only type of leishmaniasis. Anti Leishmania positive titers higher than 1:640 were observed in 78 (73.6\%) dogs.
Clinical data - Signs of VL were detected in only $34(32 \%)$ out of 106 positive dogs and in 72 $(68 \%)$ the infection was inapparent. Two or more concomitant signs of the disease were seen in the majority of dogs from AVL areas. The pattern of clinical signs observed for the disease most commonly included weight loss, apathy and emaciation.

Parasitological diagnosis - Leishmania parasites were detected in $34(97 \%)$ out of 35 dogs examined. However, the only negative dog had an IFAT of 1:40, and the others presented values higher than 1:640. Amastigotes were detected in biopsies of all five skin ulcers examined in dogs

\section{TABLE I}

Cases of visceral leishmaniasis and incidence (1/100,000 hab.) from Metropolitan Region of Belo Horizonte between 1994 and 1999

\begin{tabular}{|c|c|c|c|c|c|c|c|}
\hline \multicolumn{8}{|c|}{ Case number/incidence $(1 / 100,000)$} \\
\hline Municipality & 1994 & 1995 & 1996 & 1997 & 1998 & 1999 & Total \\
\hline Belo Horizonte & $29(1.4)$ & $46(2.2)$ & $48(2.3)$ & $47(2.2)$ & $24(1.13)$ & $29(1.4)$ & 223 \\
\hline Brumadinho & - & - & - & $1 \quad(4.9)$ & $4 \quad(15.72)$ & $4 \quad(15.3)$ & 2 \\
\hline Caeté & - & $1 \quad(2.9)$ & $2(5.7)$ & - & $1 \quad(2.81)$ & $2(5.56)$ & 9 \\
\hline Contagem & - & - & $1 \quad(0.2)$ & - & $3(0.58)$ & $1 \quad(0.2)$ & 6 \\
\hline Esmeraldas & - & $1 \quad(2.9)$ & $1 \quad(3.8)$ & - & - & - & 5 \\
\hline Ibirité & - & - & $1 \quad(1.0)$ & $3 \quad(2.92)$ & $2 \quad(1.67)$ & $14(11.1)$ & 21 \\
\hline Itabirito & - & - & - & - & - & $1 \quad(2.7)$ & 1 \\
\hline Jaboticat. & - & - & - & - & - & 1 (1.13) & 1 \\
\hline Nova Lima & - & - & $2(3.6)$ & - & $2(3.4)$ & $5 \quad(8.18)$ & 9 \\
\hline Ribeirão Neves & - & $1 \quad(0.6)$ & - & $3(1.7)$ & $4 \quad(1.8)$ & $7(3.0)$ & 15 \\
\hline Rio Acima & - & - & - & - & $1 \quad(12.7)$ & 1 (12.43) & 2 \\
\hline Sabará & $1(1.06)$ & $2(2.1)$ & $8 \quad(8.3)$ & $3 \quad(3.0)$ & $6 \quad(5.7)$ & $5 \quad(4.64)$ & 25 \\
\hline Santa Luzia & - & - & - & 3 (1.72) & $5 \quad(3.1)$ & $9 \quad(5.5)$ & 17 \\
\hline Vespasiano & $1(2.0)$ & $2(3.9)$ & 1 (1.9) & - & $1 \quad(1.56)$ & $4 \quad(6.12)$ & 9 \\
\hline Total & 31 & 53 & 64 & 60 & 52 & 83 & 345 \\
\hline
\end{tabular}

Source: Secretary of Health of the State of Minas Gerais. Calculated incidence based in a projected population by the Health Ministery.

\section{TABLE II}

Distribution of cases of visceral leishmaniasis by age group in Metropolitan Region of Belo Horizonte (1994-1999)

\begin{tabular}{crlrllll}
\hline & & \multicolumn{1}{c}{$1994-1999$} & & & \\
\hline Age group & \multicolumn{2}{c}{ Female } & \multicolumn{2}{c}{ Male } & \multicolumn{2}{c}{ Total } \\
(years) & No. & $(\%)$ & No. & $(\%)$ & \multicolumn{2}{c}{ No. } & $(\%)$ \\
\hline$<1$ & 6 & $(35.3 \%)$ & 11 & $(64.7 \%)$ & 17 & $(4.9 \%)$ \\
$1-4$ & 42 & $(50.6 \%)$ & 41 & $(49.4 \%)$ & 83 & $(24 \%)$ \\
$5-9$ & 21 & $(43.7 \%)$ & 27 & $(56.3 \%)$ & 48 & $(13.9 \%)$ \\
$10-14$ & 11 & $(42.3 \%)$ & 15 & $(57.7 \%)$ & 26 & $(7.5 \%)$ \\
$15-29$ & 25 & $(33.3 \%)$ & 50 & $(66.7 \%)$ & 75 & $(21.7 \%)$ \\
$30-60$ & 11 & $(19.6 \%)$ & 45 & $(80.4 \%)$ & 56 & $(16.2 \%)$ \\
$>60$ & 2 & $(18.2 \%)$ & 9 & $(81.8 \%)$ & 11 & $(3.1 \%)$ \\
Ignored & 10 & $(33.3 \%)$ & 19 & $(66.7 \%)$ & 27 & $(8.4 \%)$ \\
\hline Total & 128 & $(37.1 \%)$ & 217 & $(62.9 \%)$ & 345 & $(100 \%)$ \\
\hline
\end{tabular}

Source: Secretary of Health of the State of Minas Gerais 
TABLE III

Visceral leishmaniasis lethality in Metropolitan Region of Belo Horizonte between 1994 and 1999

\begin{tabular}{cc}
\hline Year & Lethality \\
\hline 1994 & $17.2 \%$ \\
1995 & $11.7 \%$ \\
1996 & $7.7 \%$ \\
1997 & $8.2 \%$ \\
1998 & $13.5 \%$ \\
1999 & $10.3 \%$ \\
\hline
\end{tabular}

Source: Secretary of Health of the State of Minas Gerais

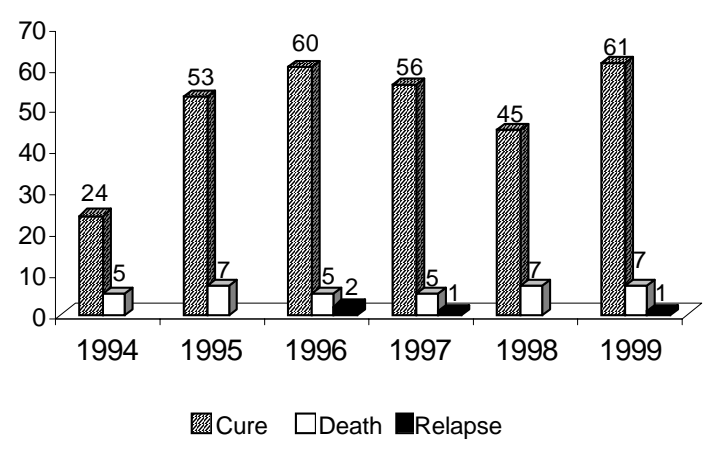

Source: Secretary of Health of the State of Minas Gerais

Distribution of visceral leishmaniasis in Metropolitan Region of Belo Horizonte in accordance with its evolution

\section{TABLE IV}

Frequency of symptoms in visceral leishmaniasis patients from Metropolitan Region of Belo Horizonte between 1994 and 1999

\begin{tabular}{lc}
\hline Symptom & Frequency \\
\hline Fever & $94.2 \%$ \\
Emaciation & $61.6 \%$ \\
Haemorrhage & $10.2 \%$ \\
Headache & $19.7 \%$ \\
Anaemia & $69.7 \%$ \\
Diarrhoea & $19 \%$ \\
Without courage & $59.5 \%$ \\
Without appetite & $45.9 \%$ \\
Nausea/vomiting & $27.6 \%$ \\
Muscle ache & $19.7 \%$ \\
Cough & $30.9 \%$ \\
Edeme & $14.3 \%$ \\
Skin dry & $12.9 \%$ \\
Splenomegaly & $77.2 \%$ \\
Hepatomegaly & $77.2 \%$ \\
\hline
\end{tabular}

Source: Secretary of Health of the State of Minas Gerais
(100\%). Imprints of ear skin from dogs with apparent and inapparent infections showed large numbers of Leishmania amastigotes.

Promastigotes were observed in culture after about 10 days with a low index of contamination when bone marrow was used. Thirty $(86 \%)$ out of 35 myelocultures were positive in NNN/LIT medium. However, culture for skin fragments were positive in only three (50\%) out of six biopsies from dogs with positive imprints.

Characterization of the parasites - Parasites were isolated in a NNN/LIT culture medium. After in vitro cultivation, the parasites were characterized as $L$. $(L$.) chagasi by the following biochemical techniques: (i) isoenzyme analysis, (ii) restriction analysis of kinetoplast DNA (KDNA), and (iii) molecular hybridization.

\section{DISCUSSION}

Several zoonoses have assumed increasing public health importance due to their urbanization. However these urban rates have increased without the incidence of the diseases being reduced in rural areas. Alterations in rural environments and the constant migratory movements of the population to the periphery of cities have facilitated this process. Leishmaniasis is a good example of this phenomenon. In the last few years it has become an important public health problem in several countries, not only because of the invasion of areas which used to be free of the disease, but also because of its re-emergence in old endemic foci (WHO 1990). In the peri-urban and urban areas, dogs are the major reservoir of the parasite (Marzochi et al. 1994), and their introduction could indeed be responsible for the origin of new foci.

The destruction of the environment with increasing social crisis and resulting migration are factors which favor the urbanization of the leishmaniases in MG. From 1989 to 1999, the greatest causes of deforestation in the MRBH were animal husbandry and agriculture. According to State Institute of Forests, Department of Forest Inspection and Control, MG, Brazil, the deforestation intended for the planting of eucalyptus trees used in blast furnaces has increased in this region due to the great number of iron and steel plants, in addition to the use of wood in households, civil construction and sawmills

In the last five years, the number of recorded cases of AVL in the MRBH has increased significantly, possibly indicating an increase in the transmission rate of the disease. The emergence of AVL in the MRBH follows the trend towards urbanization of the disease observed since the 1980s in the Northeastern region of Brazil, where it was formerly endemic only in rural areas, and in the South- 
east, where urban human cases were reported in the cities of São Paulo and Rio de Janeiro (Iverson et al. 1983, Marzochi et al. 1994).

The clinical manifestations seen in AVL patients of the MRBH are similar to the classic descriptions in the literature (Deane \& Deane 1937, Alencar \& Aragão 1955) as well as more recent observations (Marzochi, et al. 1994, Costa et al. 1995, Silva et al. 1997). These same authors stated that AVL is a disease that preferentially affects children below 9 years of age, this being the prevalent age group among our study population, with particularly high prevalence in younger children between 1-4 years of age. In accordance with previous authors, the clinical symptoms most frequently observed by us were fever, hepatosplenomegaly, anaemia and intense weight loss. From the begining of the outbreak in 1995 to 1999 we have observed a progressive increase of the disease among adults. The disease also occurs predominantly in males.

We observed that the transmission of AVL in the MRBH may be occurring in the peri-domicile or in the intradomicile, due to the infection in children with less than 1 year old of the notified cases, a fact that has been observed in other kala azar areas in Brazil (Nascimento et al. 1996).

Treatment of AVL normally involves the administration of $\mathrm{N}$-methyl-glutamine, a drug which is well tolerated by patients and gives excellent results (Berhe et al. 1993). The data show that treatment was successful in around $88.2 \%$ of patients, with only $1.2 \%$ presenting leishmaniasis relapse. We also observed a mortality rate of $10.6 \%$ among patients, probably due to delays in seeking medical attention and diagnosis of the disease. Laboratory confirmation involves detection of Leishmania parasites as well as serological tests, which normally give high rates of positivity in the presence of active disease. Careful consultation by a physician, followed by a thorough physical is necessary, examination supported by the epidemiological and laboratory data used to confirm diagnosis of VL cases. This is due to the fact that in VL-endemic areas diagnosis may be complicated by the presence of infected but asymptomatic persons as well as people suffering from various other diseases that may give false positive results to serological tests such as malaria, schistosomiasis, leprosy, and others pathologies (Silva et al. 1997).

In $\mathrm{BH}$ the prevalence of infection in dogs is higher than in man, a fact which has been observed in other endemic areas in Brazil. The canine serum prevalence based on IFAT in dogs examined by the health municipal secretary from 1994 to 1998 was $3.6 \%$.
The clinical aspects of canine AVL in the animals studied in $\mathrm{BH}$ are similar to those observed in dogs in Rio de Janeiro (Marzochi et al. 1985), the Northeast region of Brazil (Deane 1956, Alencar 1959, Alencar \& Cunha 1963) and the Mediterranean (Adler \& Theodor 1935, Malamos 1947).

The proportion of dogs with inapparent infections in RMBH was $68 \%$, similar to that observed in Rio de Janeiro (63.2\%) by Marzochi et al. (1985), in Malta (60\%) by Adler and Theodor (1935), in Greece (50\%) by Malamos (1947), and in Tuscany, Italy (50\%) by Pozio et al. (1981). The proportion encountered by Alencar and Cunha (1963) in the State of Ceará, Northeastern Brazil, was even higher: $86 \%$.

Weight loss was one of the most striking clinical manifestations as was also observed by Laveran (1917), Donatien and Lestoquard (1935), Alencar et al. (1956), Alencar (1959), and Marzochi et al. (1985) in naturally infected animals.

Cutaneous alterations that are frequently reported in canine AVL were observed during the present study. Small single or multiple cutaneous lesions were observed. These were scabbed and highly symmetrical, without pruritis and could be seen on several different areas of the body, including ears, snout, paws and genitals. Large numbers of parasites were found in local biopsies, suggesting that these areas of the body may be the points at which inoculation of the parasite by the sand fly vector occurs. These same observations were described by Vidor et al. (1991). The intense cutaneous parasitism, the presence of dogs in the peridomestic habitat and dispersal of these animals, whether by human agency or as strays, confirm the epidemiological importance of this animal as the major source of infection for Lutzomyia longipalpis in transmission of AVL to man and other animals. Nevertheless, it is interesting to note that in AVL foci dogs often show no signs of disease although they may present large numbers of amastigotes in parasitological examinations of bone marrow and skin scrapings. These animals therefore have an important role in the epidemiological cycle of AVL.

Our results show that high antibody titers occur in infected animals. The IFAT test presented titers equal to or greater than 1:640 in $73.6 \%$ of the positive dogs, even in those that showed no signs of infection, but where the parasite could be detected in bone marrow and skin, as in previous studies (Pozio et al. 1981, Marzochi et al. 1985).

Biochemical and molecular characterization of canine and human isolates of Leishmania spp., originating from different neighborhoods of $\mathrm{BH}$, confirms that $L$. $(L$. ) chagasi is the species respon- 
sible for canine and human $\mathrm{AVL}$ in $\mathrm{BH}$, as in foci thoughout this parasite's wide geographic distribution in Latin America.

\section{ACKNOWLEDGMENTS}

To the State Institute of Forest, Departament of Forest Inspection and Control, Minas Gerais, Brazil.

\section{REFERENCES}

Adler S, Theodor O 1935. Investigations on Mediterranean Kala-Azar. IX Feeding Experiments with Phebotomus perniciosus and other species on animals infected with Leishmania infantum. Proc $R$ Soc 116: 516-542.

Alencar JE 1959. Calazar Canino. Contribuição para o Estudo da Epidemiologia no Brasil, Imprensa Oficial, Fortaleza, 342 pp.

Alencar JE, Aragão T 1955. Leishmanose visceral no Ceará. Sintomas observados em 174 casos. Diagnóstico clínico. XII Congr Bras de Higiene, Belém, 28:197.

Alencar JE, Cunha RV 1963. Inquérito sobre calazar no Ceará - Novos resultados. Rev Bras Malariol D Trop 15: 391-403.

Alencar JE, Cantídio WM, Cavalcante DN 1956. Calazar em Fortaleza. XIII Congr. Bras. de Higiene, Fortaleza.

Arias JR, Monteiro P, Zicker F 1996. The re-emergence of visceral leishmaniais in Brasil. Emerging Infect Dis 2: 145-146.

Badaró R, Jones TC, Lorenço RA 1994. A prospective study of visceral leishmaniasis in an endemic area of Brazil. J Infect Dis 154: 639-649.

Badaró R, Jones TC, Carvalho EM, Sampaio D, Reed SG, Barral A, Teixeira R, Johnson Jr WD 1986. New perspectives on a subclinical form of visceral leishmaniasis. J Infect Dis 148: 1003-1011.

Berhe N, Barral-Neto M, Hailu A, Yeneneh H 1993. Relapse in Ethiopian visceral leishmaniasis (VL) patients after therapy with pentavalent antimonials: a ten years observation. Institute of Pathobiology (IPB), AddisAbeba University (AAU), Ethiopia. Ann Trop Med Parasitol 88: 289-293.

Costa JML, Viana GMC, Saldanha ACR, Nascimento MDS, Alvin AC, Burattini MN, Silva AR 1995. Leishmaniose visceral no Estado do Maranhão, Brasil. Evolução de uma epidemia. Cad Saúde Pública 11: 321-324.

Courtenay O, Santana EW, Johnson PJ, Vasconcelos IAB, Vasconcelos AW 1996. Visceral leishmaniasis in the hoary zorro Dusicyon vetulus: a case of mistaken identity. Trans $R$ Soc Trop Med Hyg 90: 498-502.

Deane LM 1956. Leishmaniose Visceral no Brasil. Estudos sobre Reservatórios e Transmissores Realizados no Estado do Ceará, Serviço Nacional de Educação Sanitária, Rio de Janeiro, 162 pp.

Deane LM, Deane MP 1937. Estudo sobre leishmaniose visceral americana nota no 1 . Aspectos clinicos da doença. O Hospital 12: 189-199.

Deane MP, Deane LM 1954. Infecção experimental do Phebotomus longipalpis em raposa (Lycalopex vetulus) naturalmente infectad pela $L$. donovani. $O$ Hospital 46: 651-653.

Donatien A, Lestoquard F 1935. Notes sur la leishmaniose viscerale canine. Bull Soc Path Exot 28: 426-431.

Grimaldi Jr G, Tesh RB 1993. Leishmaniasis of New World: current concepts and implications for future research. Clin Microbiol Rev 6: 230-250.

Iverson LB, Camargo ME, Villanova A, Reichmann MLAB, Andrade EA, Tolezano JE 1983. Inquérito sorológico para pesquisa de leishmaniose visceral em população canina-urbana do município de São Paulo-Brasil (1979-1982). Rev Inst Med Trop São Paulo 25: 310-317.

Lainson R, Shaw JJ 1987. Evolution, classification and geographical distribution. In The Leishmaniasis in Biology and Medicine, Vol 1, Academic Press Inc., London, p. 1-120.

Lainson R, Shaw JJ, Lins ZC 1969. Leishmaniasis in Brazil. IV. The fox, Cerdocyon thous (L) as a reservoir of Leishmania donovani in Pará State, Brazil. Trans R Soc Trop Med Hyg 63: 741-745.

Lainson R, Shaw JJ, Silveira FT, Braga RR 1987. American visceral leishmaniasis: on the origin of Leishmania (Leishmania) chagasi. Trans $R$ Soc Trop Med Hyg 81: 517.

Laveran A 1917. Leishmanioses. Kala-Azar, Bouton d'Orient, leishmaniose Américane, Masson et Cie., Paris, $521 \mathrm{pp}$.

Malamos B 1947. Leishmaniasis in Greece. Trop Dis Bull 44: 1-7.

Marzochi MCA, Marzochi KBF, Carvalho RW 1994. Visceral Leishmaniasis in Rio de Janeiro. Parasitol Today 10: 37-34.

Marzochi MCA, Coutinho SG, Souza W, Toledo LM, Grimaldi Jr G, Momen H, Pacheco RS, Sabroza PC, Souza MAS, Rangel Jr FB, Tramontano NC 1985. Canine visceral leishmaniasis in Rio de Janeiro, Brazil, clinical, parasitological, therapeutical and epidemiological findings. Mem Inst Oswaldo Cruz 80: 349-357.

Mello DA, Rego Jr FA, Oshozo E, Nunes VLB 1988. Cerdocyon thous $L$.(Carnivora, Canidae) naturally infected with Leishmania (donovani) chagasi (Cunha \& Chagas, 1973) in Corumbá (Mato Grosso do Sul State, Brazil). Mem Inst Oswaldo Cruz 83: 259.

Momen H, Salles CA 1985. Enzyme markers for Vibrio cholerae: identification of classical, El Tor and environmental strains. Trans R Soc Trop Med Hyg 79: 773-776.

Nascimento MDSB, Costa JMI, Fiori BIP, Viana GMC, Filho MSG, Alvin AC, Bastos OC, Nakatani M, Reed S, Badaró R, Silva AR, Burattini MN 1996. Aspectos epidemiológicos na manutenção da leishmaniose visceral no Estado do Maranhão, Brasil. Rev Soc Bras Med Trop 29: 233-240.

Pacheco RS, Lopes UG, Morel CM, Grimaldi Jr G, Momen H 1986. Schizodeme analysis of Leishmania isolates and comparison with some phenotypic techniques. In JA Riou, Leishmania Taxonomy et Phylogenese. Applications Eco-epidemiologiques, IMEEE, Montpellier, p. 57-65. 
Pacheco RS, Brandão A, Sibajev A, Cupolillo E, Momen H, Degrave W 1994. The genus Crithidia: genotypic diversity among species. J Protozool Res 4: 71-82.

Pozio E, Gradoni L, Bettini S, Gramicia M 1981. Leishmaniasis in Tuscany (Italy): VI Canine leishmaniasis in the focus of Monte Argentario (Grosseto). Acta Trop 38: 383-393.

Silva AR, Viana GMC, Varonil C, Pires B, Desterro M, Costa JML 1997. Leishmaniose visceral (calazar) na Ilha de São Luis, Maranhão, Brasil: evolução e perspectivas. Rev Soc Bras Med Trop 30: 359-368.

Silva ES, Pirmez C, Gontijo CMF, Fernandes O, Brazil RP 2000. Visceral leishmaniasis in the crab-eating fox (Cerdocyon thous) in south-east Brazil. Veterinary Record 147: 421-422.

Silveira FT, Lainson R, Shaw JJ, Povoa MM 1982 Leish- maniasis in Brazil: XVIII. Further evidence incriminating the fox Cerdocyon thous $L$. as a reservoir of Amazonian visceral leishmaniasis. Trans R Soc Trop Med Hyg 76: 6.

Southern EM 1975. Detection of specific sequences among DNA fragments separated by gel electrophoresis. J Mol Biol 98: 503-517.

Vidor E, Dereure J, Pratlong F, Dubreuil N, Bissuel G, Moreau Y, Rioux JA 1991. Le chancre d'inoculation dans le leishmaniose canine à Leishmania infantum. Prat Méd Chirurg de l'Animal de Comp 26: 133137.

WHO-World Health Organization 1990. Control of the leishmaniases. Report of a WHO Expert Committee. World Health Organization, Geneva, Switzerland. Techinical Report Series no. 793. 
292 Visceral Leishmaniasis in Belo Horizonte - Eduardo S Silva et al. 